\title{
Improving Sustainability and Encouraging Innovation in Traditional Craft Sectors: the case of the Sri Lankan Handloom Industry
}

\begin{abstract}
Purpose - The purpose of this study is to assess sustainability across the handloom industry in Sri Lanka and identify opportunities for sustainable innovations supporting new markets, development of SMEs and growth in the Sri Lankan craft sector

Design/Methodology/Approach - Using a multiple case studies methodology 10 case studies and 37 semi-structured interviews were analysed in conjunction with the triplelayered business model canvas.

Findings- The study reveals the handloom industry to be fundamentally sustainable but with structural barriers hindering innovation and growth. The environmentally conscious production process and social inclusion within weaving communities are the key driving forces of sustainability in the sector but the structure of the industry and lack of access to markets and information act as barriers to innovation and growth. The incorporation of design interventions, closed-loop manufacturing strategies and the encouragement of community-based entrepreneurship would support sustainability orientated business innovation in the handloom industry.

Originality/Value - The rapidly increasing market share for high-quality, hand-made goods indicates the potential of the creative industries to accelerate socio-economic growth. Handloom textiles is attracting growing interest in fashion markets, due to increasing concern about exploitation in production encouraging interest in the economic benefits of fairly traded, high quality materials, but also the potential contribution of handloom to sustainability in the fashion industry. The findings of this study will support the handloom industry and policy makers in developing support for sustainable innovation in the handloom industry.
\end{abstract}

Key words: Handloom industry, Innovation, Triple Layered Business Model Canvas, Sustainable textiles, Community based production, community enterprise

\section{Introduction}

The world has begun to realize the importance of creative industries, both in terms of developing creative economies and maintaining cultural identities. Widely used definition of creativity refer to the development of innovative ideas associated with knowledge through 'imagination, inspiration, ingenuity and inventiveness' and the implementation of these ideas to create new products (UNCTAD, 2008, p4). Other perspectives emphasize the importance of creativity from an economic perspective (Florida, 2002). Within developing countries, creative industries may potentially support economic growth, encourage the creation of global partnerships for development or enable new approaches 
for the inclusion of groups vulnerable to social exclusion, thus helping achieve country specific sustainable development goals (UNCTAD, 2010, p34).

Within developing countries, economic growth depends on how successfully it addresses nation-specific challenges. Challenges for policy makers include aligning economic development with personal development, enabling individual income generation and improving outcomes for groups vulnerable to social exclusion. Some developing countries recognise the potential of creative industries for economic development, and build economic strategy around them. For example, Indonesia recognizes creative industries as a major source of new entrepreneurship and income generation among young people (Santi et al., 2012) and has put in place support for innovation in the sector. As Moalosi et al., (2010) emphasize, creative industries can transform the cultural identity of communities and countries, and foster cultural diversity through promoting competitiveness, creativity, design and innovation. UNESCO (2009) concludes cultural and creative industries generate a high growth rate of GDP, Gross Value Added (GVA) and employment opportunities both in developing and developed nations. Thus we can see an interconnection between culture and the creative economy with culture, linked to creativity being considered a driver of the development in a country (UNESCO, 2013).

Handcrafted products have an important role in creative cultural industries (Bhatt, 2007; (Bhatt, 2007; Van, 2007; Jakob, 2012; Luckman, 2015; Jakob and Thomas, 2017). Craft is the application of traditional skills and knowledge, evolved over time, into relatively smallscale production. Craft is strongly associated with cultural values and traditions, history, religion, and identities of communities, including those vulnerable to social exclusion (Donkin, 2001; Wood 2011). Artisanship and the skills involved in maintaining traditional crafts travel down generations as part of the lived experience of artisans (Bhatt, 2007). In recent years the growth of the Fair Trade movement has increased interest in craft products encouraging greater awareness of the environmentally and socially responsible nature of production (Blackburn, 2007) and the potential contribution of the sector in developing creative economies, sustainable products and societies (Wood 2011; Ferraro et al.,2011).

Craft and fashion have gone together for millennia, as textiles and clothing were manually produced using traditional weaving or knitting skills with embroidery, batik or beeralu adding value to the final product. Even though the industrial revolution made labour intensive craft production uncompetitive, some textile craft sectors managed to survive providing opportunities for the creation of unique handcrafted, high-value items for today's contemporary fashion world, contrasting with mass-produced fast-fashion which is the second most polluting industry in the world due to unsustainable production and consumption practices (UN News, 2019). Rising awareness regarding the environmental impact of fashion production and consumption has increased the demand for sustainable fashion (Schrotenboer, 2013; Niinimaki, 2010). In response to this, the global fashion 
industry is seeking new ways of adopting environmentally and socially responsible products and improving manufacturing strategies (Doherty and Huybrechts, 2013; Wong et al., 2012). In this context, the integration of craft into contemporary fashion is one possible way of making fashion more sustainable (Ferraro et al., 2011). According to Hur and Beverley (2013), making use of products created through traditional craft practices can significantly increase the sustainability of both production and consumption practices of the fashion industry. Indeed, Cox and Bebbington (2015) claim craft and social sustainability share common objectives, and suggest encouraging a synergy between craft and contemporary fashion would escalate the sustainable development of the fashion industry.

This study identifies opportunities for improving sustainability and encouraging innovation within the handloom sector and proposes strategies to improve sales and marketing of products and encourage community-based entrepreneurship.

Sri Lanka has a rich history of traditional craft-based industries including textile crafts, such as handloom textiles, batik and beeralu which used to be one of the key contributors in generating household income for women. Traditional designs remain important in the almost 3000-year-old industry, with skills and designs shared down generations, usually by women. This is a highly labour intensive and low energy industry, and is thus a prime candidate for development as an environmentally friendly option for economic growth, although structural barriers to growth will need overcoming. Being located in rural areas of Sri Lanka, this industry also plays a vital role in reducing poverty, creating direct and indirect employment opportunities for the rural poor, particularly for women; enhancing rural household income and promoting local production and consumption (EDB, 2015). This industry generates significant income through both local and global trade and has potential for further growth (EDB, 2015).

The Sri Lankan handloom sector comprises three segments depending on the type of business at market place, these are: community based business, provincial council based handloom business and private business. Community based handloom weavers are scattered around the country, working as a part of a weaving village or as independent weavers. There are about 962 independent or privately owned manufacturing facilities and 771 provisional council owned production centres operated around the country (EDB, 2013). In general, these weavers produce sarees and other womenswear, menswear, curtains, bed covers, cushion covers, accessories and toys. Those products are mainly for local markets with few weavers focussing on exports. However, the rich look of finished materials, product quality and traditional identity makes the product highly valued and people with high disposable incomes consume it. Growing criticism of unsustainable production and consumption behaviours associated with fashion products has begun to 
create a demand for environmentally and socially responsible products including handcrafted apparel (Ferraro et al, 2011). Furthermore, after thirty years of civil war Sri Lanka urgently needs to develop sustainable employment opportunities, which provide a regular and sufficient income for the population, especially in rural areas. The handloom industry has been identified as an important industry with potential to improve regional economies and support rural development (Abesekara, 2011; Dissanayake et al, 2017). Among the many benefits of handloom, especially in rural areas are low capital costs and running expenses, alongside high-quality, value-added products created by skilled workers. This ecologically friendly industry, built on the undying creativity of generations, could provide new employment opportunities for rural communities, generating significant household income and supporting economic development. However, the industry is struggling to reach its full potential, with several key problems identified in this study:

- Weavers are not entrepreneurial, but rather rely on middlemen to generate markets, this significantly reduces their earnings potential

- Weavers do not innovate in design processes (either in the patterns woven or in the creation of new products), limiting access to valuable markets

- Younger people do not view handloom weaving as a viable career option, leading to a reduction in numbers of skilled artisans, which impacts on the production potential if market size was increased.

In order to expand the industry while maintaining sustainability, it is vital to understand key features of the existing business model and to investigate the possibilities for further development. This study is the first to explore sustainability and innovation with handloom communities in Sri Lanka. Government data shows almost 50\% of handloom operations have local or national government involvement in their organization, with the remainder being either independent weavers or small groups of village-based weavers. This structure means that top-down problem identification and centralized planning and implementation of solutions are often the norm, with the expertise of the weavers side-lined in the decisionmaking process. Therefore, this study took a participatory action research approach with the aim of learning from the lived experience of the weaving communities and identifying methods enabling weaving communities to take control of processes beyond production of goods.

For this research, our specific aim was to understand existing structures promoting sustainability within the sector in order to identify opportunities for improving Sustainability and encouraging innovation.

Objectives were to; 
-investigate the potential of existing business models to promote craft-based textiles as a sustainable and innovative business while reducing structural barriers to enterprise and innovation.

-identify opportunities for improvement in economic, environment and social aspects of the handloom business, enabling weavers to become more entrepreneurial and facilitating design and marketing innovations.

\subsection{Business model approaches}

Business models are a useful tool in analysing approaches to organisation strategy. (Margretta, 2002; Zott and Amit, 2010; Beattie and Smith, 2013). They are helpful in defining the competitive approach of a business through the product design and development or service offers, production cost, pricing and value proposition (Rasmussen 2007). Zott et al., (2011) have described a business model as a structure enabling analysis of the interdependent and interconnected activities of stakeholders and engagement of human, physical and capital resources so as to set effective business objectives. As Osterwalder and Pigneur (2005) explain, a business model is a conceptual tool enabling understanding of how a firm does business.

This study followed the approach of Osterwalder and Pigneur (2010), using their nineelement business canvas as a tool for analysis of data. Osterwalder and Pigneur (2010) determined these nine elements as the building blocks of a whole business process. The benefits of the nine-element business canvas are that it enables exploration of the potential for innovation in any form of business. Many practitioners (Henriksen et al., 2012; OECD, 2012; Kaplan, 2012) and researchers (Wallin et al., 2013; Bocken et al., 2013) have adopted the Osterwalder and Pigneur (2010) approach for business development and as an analytical tool. However, this model only addresses the economic aspect of a business and therefore later models incorporate environmental and social aspects as well, enabling effective evaluation of social responsibility and sustainability in the business process (Jenkins, 2009). The benefits of business models in western-style organizations is wellunderstood, however, it is less certain that these approaches will be useful for small businesses with non-standard organizational structures although exploring the potential for innovation is extremely important across all sizes and types of business. Nieto et al., (2015) findings emphasize that the family firm's efforts in innovation are more likely to achieve incremental innovations than radical innovations. It is notable that the work of Teece (2010) and Rasmussen (2007) fail to consider how their analyses can be utilized in developing countries where significant structural and socio-cultural barriers are presented. 


\subsection{Sustainable Business Model Approaches}

Given the problems with utilizing more traditional approaches to business models in the Sri Lankan context, it was important to examine sustainable business models, particularly given the low environmental impact of handloom. Sustainable business models can serve as a vehicle to coordinate technological and social innovations with system-level sustainability (Bocken et al, 2014). Lüdeke-Freund (2010) describes a sustainable business model as 'a business model that creates competitive advantage through superior customer value and contributes to a sustainable development of the company and society' (p.20). Building on Garetti and Taisch's (2012) views on sustainable manufacturing, business models offer a way for organisations to plan how to preserve the environment, while continuing to improve the quality of human life. Stubbs and Cocklin (2008) asserts that sustainable business models use both systems and firm-level perspective, build on the triple bottom line approach to define the firm's purpose and measure performance, including a wide range of stakeholders. A sustainable business model aligns the interests of all stakeholder groups, and explicitly considers the environment and society as key stakeholders, which enables the firm to capture economic value for itself through delivering social and environmental benefits (Schaltegger et al., 2012). While efficiency and quality improvements of the past may have readily translated into profits, it is not always so clear how delivering social and environmental value might translate into profit and competitive advantage for the firm. Still, the growing attention to the business model in the literature and practice suggests this is a useful framework for corporate innovation, and hence may be used to drive sustainability innovation forward (Stubbs and Cocklin, 2008; LüdekeFreund, 2010; Boon and Lüdeke-Freund, 2013).

Bocken et al. (2014) have identified eight diversified elements within a sustainable business model; maximization of material and energy efficiency, creation of value from waste, substitution with renewable and natural processes, delivering functionality rather than ownership, adaptation of the stewardship role, encourage sufficiency, re-purpose the business for society/environment and the development of scalable solutions. Thus, the model goes beyond delivering economic value and includes generating solutions improving environmental and social values as well including a broader range of stakeholders using both systems and firm-level perspectives (Lüdeke-Freund, 2010; Stubbs and Cocklin, 2008). Moreover Pal (2017) have further highlighted and compared eight major sustainable development frameworks such as ecological footprint, natural step, natural capitalism, industrial ecology, cradle-to-cradle, bio-mimetic, ZERI, and planetary boundaries and their strategic vectors in the context of the textile industry which can support the work of Bocken et al (2014).

Joyce and Paquin (2016) created the Triple Layered Business Model Canvas (TLBMC), illustrating how a business creates value by including a triple bottom line approach to sustainability. The economic layer of TLBMC is based on the nine elements business 
canvas proposed by Osterwalder and Pigneur (2010) and is further expanded to include environmental and social layers to explain how an organization creates, delivers and captures economic, environmental and social forms of value simultaneously (Joyce and Paquin, 2016).TLMBC is a well suited tool to support developing sustainable business models, through understanding both positive and negative aspects of sustainability. Thus, there are opportunities for developing detailed models of a sustainable fashion business through the application of alternative business models (Lantry, 2015) such as TLBMC while creating designs that are appropriate and incorporate important cultural aspects of a country (Hethorn, 2015). This study used TLBMC to investigate the sustainability orientation and potential for innovation of the textile handloom industry in Sri Lanka.

Handloom has been a sustainable industry since inception, due to environmental aspects such as low energy production, and social aspects such as community engagement and rural development. However, limited research has been carried out investigating the extent to which the business addresses the triple bottom line approach. This research therefore evaluates the handloom industry business model, with respect to the TLBMC proposed by Joyce and Paquin (2016), in order to investigate the sustainability orientation of the business and to identify opportunities for further improvement in economic, environmental and social aspects of the business.

\section{Methodology}

The study is based on primary data drawing on ten detailed case studies and 37 semistructured interviews enabling detailed investigation of the sustainability of existing business models in the Sri Lankan handloom industry. Case studies were selected as a qualitative holistic approach facilitating deeper discovery, enabling investigators to explore the lived experience of participants in detail (Creswell 2003; Punch, 2005; Baxter and Jack, 2008; Yin, 2009). Further, multiple case studies here facilitated cross case analysis, comparison and generalization of findings (Noor, 2008). With the nature of the proposed study, the study sample was determined by a purposive sampling strategy, focusing on particular characteristics of populations engaged in handloom business in Sri Lanka, as explained below;

1. Community based handloom business - operated by traditional weavers in weaving villages. Weaving operations are carried out in households where each family owns one or several weaving machines. Three such weaving communities were selected for the study as follows;

- Thalagune Community - the only indigenous traditional weaving community currently operating in Sri Lanka, it is also known as Dumbara weaving. Thalagune is a remote village in the Central province of Sri Lanka, where Dumbara wearers 
have been passing their weaving skills from generation to generation over many centuries.

- Madampellala community - a weaving community created by the government of Sri Lanka in 1950. However, with the introduction of the open economy in 1977, the handloom industry experienced a decline and weavers struggled to continue the business. In 2006, Madampellela weaving community was redeveloped under a government development program and the weavers were trained in new weaving techniques. This program intervened to introduce a new customer base and marketing channels to sustain the community based business.

- Marathamunie weaving community - originated as far back as the 18 th century with skills transmitted from generation to generation in the Eastern province of the country by Arabian Muslims. Currently Maruthamunai is known for its familybased and also factory-based handloom weavers. The tsunami disaster in 2004 had an adverse effect to this handloom business, however the business has been redeveloped with the government support.

2. Provincial Council based handloom business is operated under the Department of Industries of the Sri Lankan government. There are nine provincial councils and several weaving centres operating under each council. The reason for establishing these weaving centres is to provide employment opportunities for rural communities. Government support is extended to include training weavers and providing machinery and resources. Three provinces, Western, North Central and Southern, were included in this study. Western Provincial Council owns 53 production centres with 435 weavers, providing employment for around 15,000 people. Southern Provincial Council owns 81 production centres accounting for 350 weavers while North Central Provincial Council run 53 production centres with 200 weavers.

3. Private Handloom Businesses - Private handloom businesses are solely run by private businessmen who mostly manage their own production facilities in one central place. There are around 15-20 weavers working in the factory. They also work with independent and small handloom communities scattered around the country.

The nature of the business is similar for all the case study companies, however there are differences identified between the product categories and the target consumer markets. Altogether 37 semi-structured interviews were conducted. The semi structured interview schedule consisted of open-ended questions to capture craft people's opinion regarding the research questions. Data was constantly verified for consistency, reliability and quality by recording in depth and detail. The recorded interviews were accomplished with the consent of the participants. The interviews were transcribed, summarized and generated summary 
sheets (McKevitt, 2007). They were categorized into themes as explained in Yin, (2009), for the analysis. The constant comparative method was employed in raw data analysis, which is a technique based on the analytical element of grounded theory (Silverman, 2000, Jack, Moult, Anderson and Dodd, 2010). This process included review and re-review of the field observations and case studies from the data collection process, summarizing, abstracting into concepts and aggregation to themes based on the key elements presented in the TLBMC created by Joyce and Paquin (2016).

\section{Results \&Discussion}

The data collected from all 37 semi-structured interviews were analyzed in detail, by categorizing them into themes with respect to economic, social and environmental layers defined in TLBMC (Joyce and Paquin, 2016). Secondly, a cross-case analysis was conducted for the 10 case studies by comparing the similarities and differences presented in each element of the business model across cases. The study identified several common features across three categories of handloom businesses and also drawbacks, as described below under economic, environmental and social analysis.

\subsection{Analysis of the economic layer}

Economic aspects of each case were analyzed with respect to the economic layer of the TLBMC, and common elements to all case study companies are summarized in Table 1.

\section{Insert Table 1 here}

According to Table 1, analysis of the economic layer Sri Lankan handloom business model provides an insight into the alignment of nine key economic elements in the business supporting competitiveness and profitability of the business. The study found the success of each business is largely dependent on its value proposition. Businesses offer traditionally designed, ethically handmade, long lasting, customized products with unique fabric designs. Consumer attraction to those personalized fashion pieces secures a marketplace and drives the profit of the business where low volumes of production can be compromised with premium prices.

However, the analysis reveals that the lack of contemporary design skills may affect the business in the long run. Product design is largely based on traditional knowledge and weavers do not have access to initiatives where they could learn new product design skills 
or techniques. As consumers always prefer to follow latest trends (Lang et al., 2013), lack of a contemporary touch in designs can affect the sustainability and future growth of the business. Another drawback is the absence of an appropriate sales and marketing strategy. While there is a growing consumer desire to purchase handloom fashion products, investment in marketing aspects of the businesses is almost zero. Government initiatives include annual trade shows and exhibitions on behalf of the handloom industry, yet other strategies such as developing advertising and marketing campaigns, and understanding or exploiting online marketplaces or promotion are barely present.

Key partnerships among designer-manufacturer and manufacturer-end consumer are limited. Although fashion designers are involved in the business, this is as commissioners and thus there is no access to design education which would enable weavers to improve their portfolio of design. Manufacturers (weavers) are not directly connected to the endconsumer, as the business channel runs through intermediaries. This can be salesmen, retailers or designers, who gain and retain the larger portion of the profit margin of the product. While the relationship between the community weavers and end-consumer could be easily facilitated, opportunity is blocked by intermediaries providing relatively low rewards for the effort and the inherited skill of weavers and leading to a decline in numbers of weavers as young people are attracted to more lucrative occupations.

\subsection{Analysis of the environmental layer}

The environmental layer of the handloom business was analyzed using the key elements of TLBMC, incorporating the life cycle of handloom products such as; sourcing raw materials, manufacturing, distribution, use and disposal. At the time of the study, quantified carbon footprint data along the life cycle of a handloom product were not available for the 10 case studies conducted, yet this model can be used to qualitatively identify the key environmental benefits or impacts of the industry, which in turn helps in planning to improve environmental benefits. Table 2 summarizes environmental aspects identified across case studies.

\section{Insert Table 2 here}


Analysis of the environmental layer indicates an environmentally conscious production process and highlights the positive features of a sustainable business model. Currently, cotton is the dominating raw material in production, yet a trend towards using sustainable fibres, such as bamboo and banana fibres, is developing. There is also a growing demand for naturally dyed products and thus the industry is currently seeking new ways of developing use of natural dyeing processes. Weaving, which is the core manufacturing process, is entirely a manual process, with no energy use. Sewing machines are mainly used when manufacturing apparel using hand woven textiles, which generate a carbon footprint due to energy consumption. However, only 3 companies out of 10 cases own a small scale in-house sewing facility, while for all the cases, the main product is sarees which are entirely hand woven and do not require sewing.

Zero waste to landfill is another environmental benefit of this manufacturing process, as the weaving process does not generate any fabric wastes. Fabric waste generated in the cutting process is reused to make by-products such as soft toys and accessories. Wastewater released from dye plants is properly treated to meet environmental standards, then treated water is used for agricultural purposes.

While there are clear opportunities existing for end-of life product recycling or remanufacturing, little attention is given to developing other options than repurposing. Yet there are many opportunities for remanufacturing or recycling. Re-dyeing is a potential end-of-life option, especially when natural dyes are being used in the initial production process. As products are mostly manufactured using mono-materials, recycling is a viable option. If the cotton fabrics could be recycled back to obtain yarns to be reused in the manufacturing process, significant environmental benefits could be obtained by replacing virgin cotton in the supply chain.

\subsection{Analysis of the social layer}

According to Joyce and Paquin (2016), the social layer focuses on capturing key social impacts that help to improve social value creation. Table 3 provides an insight into the social aspects of the handloom industry. 


\section{Insert table 3 here}

This analysis indicates the handloom business offers important social benefits to the community: providing jobs for rural communities, improving their income levels and living standards, empowering women to take leadership roles, and providing self-development opportunities. Weavers do not have to travel to another city for employment and they can work closer to home, supporting their households and community. This also preserves the identity of the community and the product, which helps to create, harness and enable collaborative development among community members. While these social benefits are promising for community- based businesses, provisional council based and privatelyowned business set ups are also making an effort to preserve the identity and culture of the communities they work with. Production centres are located in places close to weavers homes or they are given the flexibility of working from home. Products are promoted with the identity of the community, which in turn provides strength and visibility for them in wider society.

In community-based handloom businesses, weavers work independently and there is no organizational structure as such. Therefore, training and development opportunities, and also additional support schemes are almost absent for this category of weavers. They operate with basic working conditions as looms are located in their households, similar to the model prevalent in the UK before the industrial revolution (Thompson, 1969). This independent weaving community was found to be isolated and operated with minimal support from the government. However, provisional council operated centres and private businesses do have a clearly defined organizational structure and hierarchy, where employees are provided with training and development opportunities. Working conditions are better than in households and additional support services are provided. A mechanism needs to be in place to provide training and development opportunities for the independent weavers to help uplift their social status. Developing their entrepreneurial skills, design capabilities and knowledge of retailing channels would be helpful to sustain these handloom communities in long run. 
While the handloom business generally creates social value, social and environmental impacts associated with cotton farming (chemical use, child labour, water depletion, emissions associated with importing cotton and so on) cannot be under- estimated. The social impacts of cotton as the primary raw material for the handloom industry can be considered a major social impact beyond the weaving communities in Sri Lanka, although as cotton is not grown in Sri Lanka these social and environmental costs are not directly felt in the weaving communities.

Analysis of the 10 case studies as per the economic, social and environmental layers of a sustainable business model reveals the handloom business represents a positive drive towards a sustainable business, suggesting the utility of the model in the setting of a developing country. Working with weaving communities enabled the project to identify similar problems across different structures of handloom business and it was then possible to map the data from interviews onto the canvas to identify strengths and weaknesses. Figure 1 shows the economic layer of the handloom industry, areas needing further improvements are highlighted. The economic value of the business is largely governed by consumer trends towards a long-lasting, customized and unique product range, but this relies on consumers being aware of the availability of handloom. Equally consumer tastes vary, the study found that handloom communities were not well-placed to identify or respond to differing tastes across markets even within Sri Lanka, and certainly not in the export market. In order to gain a competitive position in the market, the study highlighted several elements likely to support sustainability and innovation within the sector. Enhancing the design capabilities to cater for contemporary customer requirements is one of the key factors. This can be achieved by providing design education or with the involvement of a professional designer, enabling innovation reflecting current market trends, without losing the traditional touch. Support for effective collaborations between weavers and designers could facilitate the process of design innovation. As Sanders and Stappers (2008) stated, design intervention is a possible process to merge designers and weavers through a direct interaction and co-creation process that would possibly stimulate the growth of the business. This process can involve innovative re-designing of existing products, designing entirely new products, exploring new markets and using traditional 
skills to match the requirements of contemporary fashion markets. This process relies on reusing existing knowledge and recombining this in an innovative manner to create a novel product to fulfil the market demand (Pannozzo, 2007). However, there are structural barriers to implementation; firstly, investment in design innovation will be required. The current structure of the industry makes this difficult. There are many small groups or individuals and therefore, to make an investment cost-effective, new models of organization are needed, such as setting up co-operative businesses as community-based enterprises. Secondly, many weavers have a strong attachment to their traditional practices, and new design innovations will need to enable maintenance and celebration of traditional design practices. Thirdly, innovation in end products to create novel items for new markets will require routes for collaboration within and beyond Sri Lanka to be developed, so weavers and producers can share knowledge with product design teams to ensure the weaving communities retain ownership of their traditional processes and practices.

Weak customer relationships and inappropriate marketing channels are also significant issues that need to be addressed. Improving manufacturer-customer relationships will support the design co-creation process and cater for the actual desires and demands of the customer. Handloom products are already made with unique designs, and therefore opening up relationship links between the customer and the manufacturer could further facilitate producing customized designs for individual taste, which in turn can develop customer loyalty towards the products and the manufacturer. These types of healthy relationships are vital for market expansion and long-term economic success of the business. In developing this, exceptionally strong Smartphone penetration in Sri Lanka (131\% according to Jebamani, 2018) could be harnessed to facilitate contacts as most of our weaving communities are not easily accessible from the urban centres where markets are based. However, for rural communities smart phones (enabling internet access) are far less common than more basic phones, and this is therefore another structural barrier preventing innovation in handloom.

Analysis of the environmental layer of the handloom industry is shown in Figure 2. Production is a low energy process, where handloom machines are operated manually, and 
electricity is used only for few sewing machineries and other support services such as lighting. Therefore, handloom textile manufacturing can be identified as an environmentally sustainable process generating a very low carbon footprint, especially where a portion of the electricity is supplied from renewable resources. Major environmental impacts come from cotton farming and the import of yarns from India and China. This study identified a trend towards using other sustainable fibres such as bamboo and banana fibres, instead of cotton. However, there are only few weavers using those fibres at the moment, and the use of these fibres tends to result from special orders rather than being an integral part of production. While there are no production issues identified with these new sustainable fibres, high cost and lower availability of sufficient quantities are current concerns. If those fibre markets were to be developed, the handloom industry could be lifted into a new level of environmental sustainability. Within the current scenario, developing partnerships with small scale organic and fair-trade cotton suppliers would be helpful in minimizing environmental and social impacts of raw material sourcing. However, again there are structural barriers to accessing environmentally sustainable materials. Weavers are not easily able to source from new suppliers due to lack of knowledge about overseas suppliers and difficulties in communicating with them because of poor access to the Internet. This requires weavers to develop new skills in procurement as well as being able to place larger orders in order to purchase at a cost-effective price. Again, co-operative, community-based business organization could help overcome this barrier.

The handloom industry is already practicing 'zero waste to landfill' in its manufacturing process, although end of life disposal does generate waste. There is a possibility of incorporating closed- loop manufacturing strategies into the business where products are taken back for reuse, recycling or remanufacturing. As handloom textiles are mainly produced with a mono-material such as cotton or silk, recycling them back into yarn is a possibility and encouraging innovation in this area would be beneficial. Moreover, products can be upgraded using craft techniques such as batik, or by re-dyeing them, especially when natural dyes were used in the coloration process, fabrics can be re-dyed, depending on the compatibility of the exiting colour of the fabric. Potentially therefore, at 
the end of use phase, consumers can return their product to the manufacturer, and have them re-dyed and upgraded to an 'as new' product. This facilitates extending the product life while providing the consumer a product with completely new look. Furthermore, products such as sarees consist of 5 meters of fabric, which can be taken back, upgraded and used in manufacturing other apparel such as dresses, blouses or skirts. Currently there is a market for reusing sarees, but closed-loop manufacturing, even within Sri Lanka still has structural barriers to overcome, and systems and incentives need to be developed to support manufacturers in organizing this.

As shown in Figure 3, the handloom industry represents a socially responsible business in various aspects. The business is tightly connected with the social and traditional culture, providing rural development, employment opportunities and generating household income, and employment and leadership opportunities for women. However, community- based handloom weavers operate independently and are thus less advantaged in terms of training, development opportunities and other support services which provisional council and private business-based weavers are offered. Their strength comes from being a part of a weaving village, where their identity and product ownership are secured. Developing entrepreneurial skills among community weavers would facilitate the self-development of the community and create new job opportunities. Community-based entrepreneurship is a social enterprise model (such as co-operative forms of business) geared towards achieving a community's economic and social goals (Peredo and Chrisman, 2006). As noted above, a number of issues identified in the business model could be addressed if weavers were organized into more effective business units. Again, there are structural barriers as well as socio-cultural issues to overcome. Weavers are accustomed to autonomy, even where they can see that there might be a route to efficiency and profit from working in a different way. One possible solution is for government to intervene in developing the entrepreneurship skills of the community-based weavers, by providing both financial support and human resources expertise. As the majority of community-based weavers have inherited craft skills as opposed to the externally trained weaves in private businesses, developing those craft communities would help to preserve the traditional identity and cultural aspects of the business, ensuring the survival of both tangible and intangible cultural heritage for future 
generations. In addition, this approach would enable more efficient procurement and provide a means for design innovations to be introduced efficiently.

\section{Conclusion}

This study explored the Sri Lankan handloom industry from a triple bottom line perspective. Results from the study indicate that the industry offers a promising approach towards a sustainable business model. The analysis provides useful insights to drive sustainability-oriented business innovation. Growing consumer awareness and demand for sustainable products could accelerate the market expansion of handloom business if interventions proposed here were adopted. To sustain the growth and expansion of the business, implementation of design intervention and developing entrepreneurial skills of the weaving communities are recommended.

There is a need for more research in craft sectors of developing countries. There is clearly potential for innovation within and expansion of the sector but there is only limited understanding of the socio-cultural and structural barriers to innovation and growth. A limitation of this study was lack of capacity to explore the concerns of handloom weavers over the reluctance of younger generations to learn craft skills or to remain within the community. The flight of young people from craft sectors has not been explored by academics, but understanding the phenomenon is central to stemming the loss of future handloom weavers from their communities. It is also important to understand how stronger business networks can be created between the developed and developing world to support craft sectors. Although globalisation has increased knowledge of products such as handloom in the developed world, weavers have very limited access to markets and need support to build new networks beyond their community and country.

There is an emerging market for exclusive, hand-made, products with cultural integrity and provenance as opposed to mass manufactured, cheap, throwaway products. Consumers are increasingly beginning to respect and value ethical, fair and green products, as they become more conscious of the influence of their consumption pattern on the environment and society. Thus, many more consumers direct their choices to handmade, local and eco 
products following the trend for sustainability, and this is a growing market. Handloom products carry the local identity, cultural value, and sustainable manufacturing process; thus, they are in a strong position to react to this current market trend but there remain structural barriers to progress. This should be addressed by changes in government policy and practice. Such changes could encourage growth in the industry through the development of community-based enterprise, closed-loop manufacturing, use of sustainable raw materials and innovations in design and marketing.

\section{References}

Abeysekara, N., (2011). "A case for a creative economy in Sri Lanka" The Nation Available at: www.nation.lk/ 21/05/15/newsfe11.html .

Baxter, P., Jack, S., (2008). “Qualitative Case Study Methodology: Study Design and Implementation for Novice Researchers". The Qualitative Report, Vol. 13 No.4, pp. 544559. https://nsuworks.nova.edu/tqr/vol13/iss4/2

Beattie, V., Smith, S.J.,(2013). "Value Creation and Business Models: Refocusing the Intellectual Capital Debate". British Accounting Review. Vol.45 No.4, pp. 243-254. DOI: http://dx.doi.org/10.1016/j.bar.2013.06.001

Benson, B., Crego, E.T., Drucker, R.H., (1990). "Your Family Business: A Success Guide for Growth and Survival'. Dow Jones-Irwin, Homewood, IL

Bhatt, J., (2007). "Philosophy and practice of crafts and design". Available at: https://www.india-seminar.com/2007/570/570_jatin_bhatt.htm

Blackburn, W. R., (2007). The sustainability handbook: The complete management guide to achieving social, economic, and environmental responsibility. Environmental Law Institute.

Bocken, N. M. P., Short, S. W., Rana, P., Evans, S. (2013). “A value mapping tool for sustainable business modelling”. Corporate Governance, Vol. 13, No. 5, pp. 482-497. DOI: $\underline{\text { http://dx.doi.org/10.1108/CG-06-2013-0078. }}$

Bocken, N. M. P., Short, S. W., Rana, P., Evans, S., (2014). "A literature and practice review to develop sustainable business model archetypes". Journal of Cleaner Production. Vol. 65, No. 2014, pp. 42-56. DOI:

https://doi.org/10.1016/j.jclepro.2013.11.039 
Boon N. M.P. and Lüdeke-Freund, F., (2013). "Business models for sustainable innovation: state-of-the-art and steps towards a research agenda". Journal of Cleaner Production, Vol. 45,pp. 9-19. DOI: 10.1016/j.jclepro.2012.07.007

Casadesus-Masanell, R., Ricart, J. E., (2010). "From strategy to business models and onto tactics”. Long range planning, Vol. 43 No. 2-3,pp.195-215. DOI:

10.1016/j.lrp.2010.01.004

Cox, E., Bebbington, J.,( 2015). “Craft and Sustainable Development: An Investigation”. Available at: https://cgi.standrews.ac.uk/media/sasi/documents/Craft\%20and\%20Sustainable\%20Development.pdf

Creswell, J., (2003). Research Design: Qualitative, Quantitative and Mixed Method Approaches, Second edn, SAGE Publication.

Dewulf, J., Meester, S. D., Alvarenga, R., (2016). Sustainability assessment of renewablesbased products: Methods and case studies. Chichester, UK; Hoboken, NJ: John Wiley \& Sons. ISBN: 978-1-118-93394-

Dissanayake, D. G. K., Perera, S., Wanniarachchi, T., (2017). "Sustainable and ethical manufacturing: a case study from handloom industry". Textiles and Clothing Sustainability, Vol. 3, No. 1, pp. 1-10. DOI: 10.1186/s40689-016-0024-3

Doherty, B., Huybrechts, B. (2013). "Connecting producers and consumers through fair and sustainable value chains". Social Enterprise Journal, Vol. 9, No.1, pp. 4-10.

DOI.org/10.1108/SEJ-05-2013-0021 .

Donkin, L. (2001). "Crafts and conservation: Synthesis report for ICCROM". Available at:https://www.iccrom.org/sites/default/files/2017-

12/iccrom_02_craftsandconservation_en.pdf.

Dumas, C., (1998). "Women's pathways to participation and leadership in the familyowned firm". Family Business Review. Vol.11 No.3, pp.219-228.

EDB (2013) "Export Performance Report,. Export Development Board". http://www.srilankabusiness.com/exporters/export-performance-report.html (Accessed February 22, 2018)

EDB (2015), “Trade Statistics - Sri Lanka Exports Development Board”, Available at: http://www.srilankabusiness.com/edb/trade-statistics.html

EDB (2017), "Export performance", Available at: http://www.srilankabusiness.com/exporters/export-performance-report.html 
Ferraro, E., White, R., Cox, E., Bebbington, J., Wilson, S.(2011). "Craft and sustainable development: reflections on Scottish craft and pathways to sustainability". Craft+ design enquiry, Vol.3,pp. 1-26.

Florida, R. (2002). The rise of the creative class (Vol. 9). New York: Basic books.

Francis, A.E., (1999). "The Daughter also Rises: How Women Overcome Obstacles and Advance in the Family-Owned Business". Rudi Publishing, San Francisco, CA.

Garetti, M., Taisch, M. (2012). "Sustainable manufacturing: trends and research challenges". Production planning \& control, Vol,23 No.2-3, pp. 83-104.

DOI abs/10.1080/09537287.2011.591619.

Hethorn, J., (2015). "User-centered innovation: Design thinking and sustainability. Sustainable fashion: What's next?”.2nd Edition, pp. 51-75. New York, NY: Bloomsbury.

Hur, E. S., Beverley, K. J. (2013), September. "The role of craft in a co-design system for sustainable fashion". In Making Futures: The Crafts in the Context of Emerging Global Sustainability Agendas (Vol. 2). Leeds.

Jack, S., Moult, S., Anderson, A.R., and Dodd, S., (2010). "An entrepreneurial network evolving: Patterns of change". International Small Business Journal. Vol.28 No.4, pp315337. DOI: https://doi.org/10.1177/0266242610363525 .

Jakob, D. (2012). "Crafting your way out of the recession? New craft entrepreneurs and the global economic downturn". Cambridge journal of regions, economy and society, Vol. 6, No. 1, pp. 127-140.doi.org/10.1093/cjres/rss022

Jakob, D., Thomas, N. J.(2017). "Firing up craft capital: the renaissance of craft and craft policy in the United Kingdom". International Journal of Cultural Policy, Vol.23 No. 4, pp. 495-511.

Jebamani, D., (2018) Digital Data for Sri Lanka, https://www.linkedin.com/pulse/digital-data-2018-sri-lanka-dinesh-jebamani/

Jenkins, H., 2009. A ‘business opportunity' model of corporate social responsibility for small-and medium-sized enterprises. Business ethics: A European review, 18(1), pp.2136.

Joyce, A., Paquin, R. L.(2016). “The triple layered business model canvas: A tool to design more sustainable business models". Journal of Cleaner Production, Vol. 135, pp. 14741486. doi.org/10.1016/j.jclepro.2016.06.067 
Kaplan, S. (2012). The Business Model Innovation Factory: How to Stay Relevant when the World is Changing, Wiley.

https://onlinelibrary.wiley.com/doi/book/10.1002/9781119205234

Kotler, P. (2011). "Reinventing marketing to manage the environmental imperative" Journal of Marketing, Vol. 75 No.4, pp. 132-135.

https://journals.sagepub.com/doi/10.1509/jmkg.75.4.132

Lang, C., Armstrong, C.M., and Brannon, L.A., (2013). "Drivers of clothing disposal in the US: An exploration of the role of personal attributes and behaviors in frequent disposal". International Journal of Consumer Studies. Vol.37 No.6, pp706-714. DOI: doi.org/10.1111/ijcs.12060

Lantry, J. L., (2015). “Artisan culture: rethinking sustainability through collaborative exchange between emerging Australian designers and Indian artisans in fashion and textiles (Doctoral dissertation). Available at; https://opus.lib.uts.edu.au/handle/10453/52949(Accessed Nov27, 2019)

Luckman, S.(2015). Craft and the creative economy. Springer.

Lüdeke-Freund, F.(2010). "Towards a conceptual framework of'business models for sustainability". Knowledge collaboration \& learning for sustainable innovation, R. Wever, J. Quist, A. Tukker, J. Woudstra, F. Boons, N. Beute, eds., Delft. DOI.org/10.1016/j.jclepro.2012.07.00

Magretta, J.(2002). "Why Business Models Matter”.Harvard Business Review. https://hbr.org/2002/05/why-business-models-matter

Moalosi, R., Popovic, V., \& Hickling-Hudson, A.(2010). "Culture-orientated product design”. International Journal of Technology and Design Education, Vol.20 No.2, pp.175-190.

McKevitt, C., (2007). "Doing Health Anthropology: Research Methods for Community Assessment and Change". Medical Anthropology Quarterly. Vol.21 No.4, pp416-417. doi 10.1525/maq.2007.21.4.416

Nieto, M. J., Santamaria, L., and Fernandez, Z. (2015). "Understanding the innovation behavior of family firms". Journal of Small Business Management, Vol.53 No.2, pp.382399. DOI: $10.1111 /$ jsbm. 12075 
Noor, K. B. M. (2008). "Case study: A strategic research methodology". American journal of applied sciences. 5(11), pp1602-1604. doi 10.3844/ajassp.2008.1602.1604.

Henriksen,K., Bjerre,M., Øster,J. And Bisgaard, T. (2012)

"Green Business model innovation - Policy report". Available at: www.nordicinnovation.org/.../2012/2012_16\%20Green\%20Business\%20Mode1\%20I...

OECD Report (2012) . "Key role of cultural and creative industries in the economy". Available at: http://www.oecd.org/site/worldforum06/38703999.pdf (Accessed April 22, $\underline{2019)}$

Olson, P.D., Zuiker, V. S., Danes, S. M., Stafford, K., Heck, R. K., and Duncan, K. A. (2003). "The impact of the family and the business on family business sustainability". Journal of business venturing, Vol.18 No.5, pp639-666.

Osterwalder, A., Pigneur, Y., \& Tucci, C. L. (2005). "Clarifying business models: Origins, present and future of the concept". Communications of the Association for Information Science (CAIS), Vol. 16: pp. 1-25.

Osterwalder, A., Pigneur, Y.(2010). Business model generation: a handbook for visionaries, game changers, and challengers. John Wiley \& Sons.

Pal, R. (2017). "Sustainable design and business models in textile and fashion industry". In Muthu S. (eds.) Sustainability in the Textile Industry . pp. 109-138. Springer, Singapore. DOI: 10.1007/978-981-10-2639-3_6OAI

Pannozzo, A. (2007). "The (Ir) relevance of technology: Creating a culture of opportunity by design”. Design Management Review, Vol. 18, No. pp 18-24. DOI: $\underline{10.1111 / j .1948-}$ 7169.2007.tb00090.x

Polsa, P. (2016). "Marketing thought follows the circle of consumption". Australasian Marketing Journal, Vol. 24 No.3, pp. 252-253.

Peredo, A. M., Chrisman, J. J.( 2004). "Toward a theory of community-based enterprise". Academy of Management Journal, Vol. 31, No.2. pp 309-328. DOI:

10.5465/AMR.2006.20208683

Punch, K. F. (2005). Introduction to Social Research: Quantitative and Qualitative Approaches. SAGE Publications

Rasmussen, B., (2007). "Business Models and the Theory of the Firm". Working Paper. Available at: http://vuir.vu.edu.au/15947/ 
Richardson, J. (2008). "The business model: an integrative framework for strategy execution”. Strategic Change. Vol. 17 No.5-6, pp.133-144.

Santi, S., Rucita, C.P., Hani, U., Rachmania, I.N. (2012). "Women Empowerment through Creative Industry: A Case Study". Procedia Economics and Finance. Vol. 4. Pp. 213-222. DOI 10.1016/S2212-5671(12)00336-X.

Schaltegger, S., Lüdeke-Freund, F., Hansen, E. G. (2012). "Business cases for sustainability: the role of business model innovation for corporate sustainability". International Journal of Innovation and Sustainable Development, Vol. 6, No.2, pp 95-119.

Schrotenboer, A. L.(2013). Ethical Fashion and Its Effects on Consumer Buying Behavior. Available at:

https://docs.lib.purdue.edu/cgi/viewcontent.cgi?article=1016\&context=hhstheses

Silverman, D., (2000).“Doing Qualitative Research: A Qualitative Handbook”. London: Sage.

Stubbs, W., Cocklin, C.(2008). "Conceptualizing a 'Sustainability Business Model”. Organization \& Environment, Vol. 21, No.2, pp 103-127.

Teece, D.J.(2010). “Business Models, Business Strategy and Innovation”, Long Range Planning, Vol. 43 No.2-3, PP 172-194.

UN News, 2019, https://news.un.org/en/story/2019/03/1035161(Accessed on 02nd December 2019)

UNCTAD (2008) . "Creative Economy Report; The Challenge of Assessing the Creative Economy: Towards Informed Policy-making". Available at: http://unctad.org/en/docs/ditc20082cer_en.pdf.

UNCTAD (2010). "Creative Economy Report; A Feasible Development Options" Available at: https://unctad.org/en/docs/ditctab20103_en.pdf 
UNESCO (2009). Review of The framework for cultural statistics, Belén Usero., HYPERLINK "https://www.tandfonline.com/author/Usero\%2C+Bel\%C3\%A9n" HYPERLINK

"https://www.tandfonline.com/author/Angel+del+Br\%C3\%ADo\%2C+Jes\%C3\%BAs" HYPERLINK "https://www.tandfonline.com/author/Usero\%2C+Bel\%C3\%A9n"Jesús Angel del Bríopp 193-197, https://doi.org/10.1080/09548963.2011.563915

UNESCO (2013). Creative Economy Report; Special Edition. Available at: http://www.unesco.org/culture/pdf/creative-economy-report-2013.pdf (Accessed on 13th June 2019)

Van der Pol, H.(2007). Key role of cultural and creative industries in the economy. Available at: https://www.oecd.org/site/worldforum06/38703999.pdf

Wallin, J., Chirumalla, K., Thompson, A. (2013). "Developing PSS Concepts from Traditional Product Sales Situation: The Use of Business Model Canvas”. In: Meier H. (eds) Product-Service Integration for Sustainable Solutions. Lecture Notes in Production Engineering. Springer, Berlin, Heidelberg, pp 263-274.

Ward, J. L., (2011). “Keeping the Family Business Healthy: How to Plan for Continuing Growth, Profitability, and Family Leadership". New York: Palgrave Macmillan.

Whiteside, M. F., and Brown, F. H., (1991). "Drawbacks of a dual systems approach to family firms: Can we expand our thinking?”. Family Business Review, Vol.4 No.4, pp 383-395.

Wong, C. W., Lai, K. H., Shang, K. C., Lu, C. S., \& Leung, T. K. P. (2012). “Green operations and the moderating role of environmental management capability of suppliers on manufacturing firm performance". International Journal of Production Economics, Vol. 140, No.1, pp.283-294.

Wood, S. (2011). "Sustaining crafts and livelihoods: handmade in India". Craft+Design Inquiry. Vol. 3, pp 1-15.

Yin, R. K. (2009). Case study research: Design and methods. 4th ed: Sage Publications.

Zott, C., Amit, R. (2010). "Designing your future business model: an activity system perspective”. Long Range Planning. Vol.43, pp.216-226.

Zott, C., Amit, R., Massa, L. (2011). “The business model: recent developments and future research". Journal of Management. Vol.37, pp. 1019-1042. 
